\title{
HOMENAGEM \\ Juarez Rubens Brandão Lopes (1925-2011)
}

Em sua notável e prolífica carreira de pesquisador e professor, Juarez Rubens Brandão Lopes reuniu aspectos marcantes da própria trajetória das ciências sociais no Brasil, seja do ponto de vista das temáticas abordadas e do modo de tratá-las, seja por conta de suas variadas e produtivas vinculaçōes institucionais.

Juarez Brandão Lopes frequentou a Escola Livre de Sociologia e Política de São Paulo durante os anos áureos daquela instituição, no final da década de 1940, depois de trocar uma formação inicial de engenheiro pela de sociólogo. Formado em 1950, passou quase os três anos seguintes na Universidade de Chicago, realizando estudos de pós-graduação. De volta ao Brasil, dedicou-se inicialmente a pesquisas sobre educação, escolha ocupacional e mobilidade social, destacando o impacto do paulatino estabelecimento de um sistema de educação de massa no país. $\mathrm{Na}$ virada da década de 1950 e 1960, realizou uma pesquisa pio- neira sobre o emergente operariado fabril ("O ajustamento do trabalhador à indústria: mobilidade social e motivação"), problematizando sua origem rural e suas formas de solidariedade, associativismo sindical e participação política. Essas experiências de pesquisa acabaram incorporadas em Sociedade industrial no Brasil, tese publicada em 1964, com a qual obteve o doutorado na antiga Faculdade de Filosofia, Ciências e Letras da USP.

Ao longo da década de 1960, prosseguiu seus estudos sobre desagregação da sociedade rural patrimonialista, urbanização, burocratização, estratificação social e transformações políticas, articulando um arsenal conceitual de inspiração weberiana a um tratamento rigoroso de dados empíricos, sempre aberto a diferentes pontos de vista disciplinares, da economia à antropologia. Desses esforços surgiram livros Crise do Brasil arcaico (1967) e Desenvolvimento e mudança social (1968) - este último, em particular, é uma síntese 
magistral do estado das pesquisas sociológicas do período sobre a formação da sociedade urbano-industrial do Brasil.

Embora vazados por uma linguagem próxima da chamada "sociologia da modernização", esses trabalhos de Juarez Brandão Lopes continham uma incisiva crítica a certa interpretação dualista então em voga, sobretudo ao enfatizar a reestruturação (mais do que a mera "sobrevivência") de formas sociais patrimonialistas no interior de uma organização social emergente, mais ampla e mais complexa. Mostraram-se, assim, capazes de propiciar tanto uma visão global dos processos de desenvolvimento econômico e de reorganização social e política, como propor pontos de partida para novas pesquisas, posteriormente levadas a cabo. Exemplo disso é sua reflexão pioneira sobre os operários metalúrgicos, ressaltando as aspirações de ascensão social e a grande mobilidade profissional dos trabalhadores de baixa qualificação, que alternavam ocupações agrícolas, comercias e industriais, bem como suas formas de solidariedade orientadas por um "sentimento de revolta da classe baixa" - que faziam com que o próprio sindicato fosse visto pelos operários "como algo feito por outros para eles". (Em entrevista recente à $R B C S$, Leôncio Martins Rodrigues lembrou que o próprio Juarez notara, com humor, que essa sua frase "acabou sendo uma das mais citadas em estudos sobre o comportamento operário no Brasil".) Temas como o impacto do controle da natalidade e a expansão dos meios de comunicação de massa receberam também uma atenção pioneira nesses trabalhos da década de 1960, sinalizando sua preocupação com os impactos das inovações tecnológicas nos estilos de vida, junto ao interesse persistente em desvendar processos socioeconômicos mais amplos a partir de enfoques localizados.

Livre-docente em Estudos Sociais e Econômicos na Faculdade de Arquitetura e Urbanismo (FAU) da USP, a partir de 1966 - cadeira que contribuiu diretamente para reformatar - e professor titular naquela instituição, a partir de 1972, Juarez Brandão Lopes passou a lecionar ali cursos sobre desenvolvimento do capitalismo. Foi um dos fundadores do Cebrap, em 1969, tendo oferecido sua própria casa para as reunióes de construção do projeto daquela instituição, num momento par- ticularmente difícil da vida política e acadêmica nacional. Embora não fosse marxista de formação, fez parte do célebre grupo de estudos sobre $O$ Capital, que impulsionou a difusão do marxismo acadêmico em São Paulo. Na segunda metade da década de 1970, atuou na FFLCH-USP como professor convidado da área de Ciência Política, ministrando cursos de Formação do Estado Nacional e Introdução à Ciência Política para estudantes de graduação em ciências sociais - cursos memoráveis para os que tiveram o privilégio de assisti-los, nos quais imprimia sua verve e energia incomparáveis, aliadas à clareza e à inteligibilidade características de seu estilo acadêmico.

Nos anos de 1980, Juarez ingressou no Instituto de Filosofia e Ciências Humanas da Unicamp, participando da implantação do doutorado em Ciências Sociais dessa instituição. Atuou também como professor na Escola de Administração da Fundação Getulio Vargas e como pesquisador e docente convidado em diversas instituiçôes nacionais e estrangeiras. Ao longo de sua carreira, exerceu cargos de gestão e governo na esfera federal, como diretor do CNPq, secretário-adjunto da Secretaria de Planejamento da Presidência da República e vice-presidente do Ipea (Instituto de Pesquisa Econômica Aplicada).

De modo semelhante a outros companheiros de geração, a trajetória de Juarez Brandão Lopes corresponde a um momento de institucionalização das ciências sociais, em que as fronteiras disciplinares no âmbito do ensino e da pesquisa eram fluidas, ou ao menos não demarcavam especializaçôes tão nítidas quanto parece hoje em dia. Mas talvez ele tenha posto em prática um jeito peculiar de transpor e transgredir fronteiras, coerente com sua formação na antiga Escola Livre de Sociologia e Política, onde sociologia, antropologia, demografia, geografia humana, economia e mesmo psicanálise compareciam com peso equivalente, conjugadas com a experiência em pesquisa de campo, de forte inspiração etnográfica. Esse casamento entre teoria e pesquisa foi por ele reencontrado na Universidade de Chicago nos anos de 1950 (reencontro nada inesperado; afinal era de lá que viera a orientação que prevalecia na antiga ELSP); e de alguma maneira ele sempre se empenhou em 
restaurá-lo nas universidades e nos centros de pesquisa por onde passou. Empregou sua formação e experiência no esforço de compreender o Brasil, preocupado com processos e tendências, fundindo diferentes perspectivas e contribuições. Foi interdisciplinar e transdisciplinar, a seu modo. Não se acomodava aos escaninhos do conhecimento. Preferia definir-se como "cientista social" - figura que, hoje, parece cada vez mais rara. 